\title{
In-Situ Ionic Imprinted Membrane (IIM) Synthesis Based on Acetic Polyeugenoxy Acetyl Tiophen Methanolate for Gold(III) Metal Ion Transports
}

\author{
Muhammad Cholid Djunaidi*, Pardoyo, Didik Setiyo Widodo, \\ Retno Ariadi Lusiana, and Anggun Yuliani \\ Department of Chemistry, Faculty of Science and Mathematics, Diponegoro University, \\ Jl. Prof. Soedharto SH, Tembalang, Semarang 50275, Indonesia
}

\section{* Corresponding author:}

tel: $+62-81226328778$

email: choliddjunaidi@live.undip.ac.id

Received: September 23, 2019

Accepted: February 3, 2020

DOI: $10.22146 /$ ijc. 49941

\begin{abstract}
In this research, Polyeugenoxy Acetyl Tiophen Methanolate (PEATM)-Au ionic imprinted membrane (IIM) was synthesized. IIM is a PEATM based membrane that has Au(III) ion molds. The PEATM synthesis was analyzed using FTIR spectroscopy, and its relative molecular weight was determined by the viscometry method. To find out the presence of $A u(I I I)$ templates on IIM, FTIR spectroscopy and SEM-EDX were used. The results of FTIR spectroscopy \& SEM-EDX analysis prove the existence of $A u(I I I)$ metal ion templates at IIM. Through FTIR spectra, it could be seen that the absorption area of the -OH group was widening. In the IIM, the CS group wave number $\left(702.9 \mathrm{~cm}^{-1}\right)$ also shifted to a larger wavenumber $\left(848.68 \mathrm{~cm}^{-1}\right)$, this is likely due to the presence of PEGDE as a crosslinker agent and PVA as a plasticizer on the membrane that interacts with PEATM-Au, which influences the shift of vibrational wavenumber of CS bonds. It was also found that the most effective $\mathrm{pH}$ of the feed phase for the transport was at $\mathrm{pH} 3$, and the most optimum transport time was $24 \mathrm{~h}$ for IIM and $48 \mathrm{~h}$ for NIM. The transport of $\mathrm{Au}$ in binary mixture of $\mathrm{Au} / \mathrm{Cd}, \mathrm{Au} / \mathrm{Fe}$, and $\mathrm{Au} / \mathrm{Pb}$ also proves that the presence of $A u(I I I)$ ions in IIM makes IIM more selective to Au(III) metal ions than NIM when used for the transport process as it transports Au more than the other metals. These results were as expected by using the HSAB theory as its groundwork.
\end{abstract}

Keywords: ionic imprinted membrane; gold metal ion; transport; selectivity; binary metal ions

\section{- INTRODUCTION}

Gold is a precious metal that is widely applied in various fields. In the electronics field, gold is used as a coating material for electronic components because of its corrosion-resistant properties, and its conductivity is almost $100 \%$. During this time, gold can be obtained from ore contained in nature with relatively small amounts, namely in 1 ton of gold ore, containing only about 5-30 g of gold metal [1]. Given the high demand for the gold metal, various attempts were made to find new sources of gold apart from panning for gold ore in nature. One promising source of gold is from electronic equipment waste. When compared with the concentration of gold in the ore, the concentration of gold in electronic waste is relatively higher at $200 \mathrm{~g}$ in each ton of electronic waste
[2]. The process of recovering (recovering) gold from electronic waste is often done using hazardous materials, such as washing using cyanide salt of nitric acid and the amalgamation process using mercury (Hg) [3-4]. Besides requiring relatively high costs (for the management of secondary waste generated from the recovery process), this process is certainly dangerous. In acidic water, mercury can be converted to methyl mercury and can harm the fetus and can cause damage to the brain. Therefore, various attempts were made to find an environmentally friendly alternative method for the recovery of gold metal from electronic waste.

Supported Liquid Membrane (SLM) is one of the environmentally friendly methods that can be used for gold metal recovery from electronic waste. The 
advantages of this SLM method are that it has high selectivity, a broad spectrum of separation, and is easy to do. The SLM method still has weaknesses, namely low stability against leakage of carrier compounds during the transport process, causing the source and receiver phases to mix; besides, SLM also has a short lifetime. One effort to overcome SLM weaknesses is by mixing a carrier compound with plasticizer and supporting polymer to be made into a solid membrane in the form of thin, stable, and flexible films. The separation mechanism of target compounds on this solid membrane is almost the same as the SLM method [5].

Ionic imprinted membrane (IIM) is a membranebased on a functional polymer that has an ionic mold. The printed ion is used as a template that acts as a group to recognize the target ion. The existence of ion templates aims to make the membrane selective to the target ion when used for the transport process through a simple static adsorption mechanism of permeation [6-7]. Selectivity in transport can be achieved because during the process of removing template ions from the polymer matrix will cause the arrangement of ions printed polymer [8].

The ester derivative of the eugenol compound has been proven to be used as a liquid membrane carrier with selectivity, which can be adjusted depending on the functional group included [9]. In previous studies, esters of sulfur (E) functional group eugenol, namely thiophene2-methyl-2-eugenoxy acetate as carrier compounds in liquid membranes for the recovery of soft metal $\mathrm{Ag}^{+}$ (silver ions) [10]. The research is based on the theory of HSAB (Hard Soft Acid Base), so that sulfur functional groups in soft carrier compounds will bind soft metals (such as $\mathrm{Cd}^{2+}, \mathrm{Ag}^{+}$, and $\mathrm{Au}^{3+}$ ) [11-10].

In this research, PEATM ionic imprinted membrane (IIM) synthesis was used using eugenol derivative polymer base, in the form of polyeugenoxy acetyl thiophene methanolate (PEATM). The PEATM IIM was applied as an $\mathrm{Au}$ (III) ion-selective transport membrane whose selectivity would be compared to NIM (as a control). PEATM was chosen as the base for IIM and NIM in this study due to its sulfur-containing functional group, 2-thiophenmethanol. The carrier used in this membrane was chosen according to the HSAB theory (grouping of acid-base based on hardness and softness), in which gold(III) as the targeted ion could be categorized into a soft acid metal ion that forms a stronger complex with soft base donor atoms (such as sulfur from 2thiophenmethanol). The presence of the Au template on IIM synthesized in-situ is expected to increase membrane selectivity for the recovery of $\mathrm{Au}$ ions in solution. This research is the first research to use PEATM as an ionic imprinted membrane for selective transport of $\mathrm{Au}(\mathrm{III})$ known. Previous research about PEATM synthesis has been done as a new selective carrier using the bulk liquid membrane method. The PEATM was then used as a BLM carrier to separate a mixture of $\mathrm{Cd}^{2+}, \mathrm{Cr}^{3+}$, and $\mathrm{Cu}^{2+}$ [12]. Through this research, it is proven that PEATM-Au ionic imprinted membrane could be used to selectively remove $\mathrm{Au}(\mathrm{III})$ from its binary metal ions.

\section{- EXPERIMENTAL SECTION}

\section{Materials}

The materials used in this research were Eugenol p.a. (Mv $169 \mathrm{~g} / \mathrm{mol}$ ), polyvinyl alcohol p.a. (Mv 130,000 g/mol), $\mathrm{Na}_{2} \mathrm{SO}_{4}$ p.a., Thionil chloride p.a., polyethylene glycol diglycidyl ether p.a. (Mv $500 \mathrm{~g} / \mathrm{mol}$ ), NMP p.a. from Sigma Aldrich, $\mathrm{HCl}$ p.a., Methanol p.a., $\mathrm{NaOH}$ p.a., $\mathrm{BF}_{3} \mathrm{O}\left(\mathrm{C}_{2} \mathrm{H}_{5}\right)_{2}$ p.a., 2-thiophenmethanol p.a., $\mathrm{NaHCO}_{3}$ p.a., $\mathrm{KCl}$ p.a., $\mathrm{HAuCl}_{4}$ p.a., $\mathrm{Fe}\left(\mathrm{NO}_{3}\right)_{3}$ p.a., $\mathrm{Pb}\left(\mathrm{NO}_{3}\right)_{2}$ p.a., $\mathrm{Cd}\left(\mathrm{NO}_{3}\right)_{2}$ p.a. from Merck and double-distilled water from Bratachem.

\section{Instrumentation}

The equipment used in this research were Standard research glass equipment, petri dish, analytical balance (Mettler-200), furnace, stirrer, desiccator, thickness meter, $\mathrm{pH}$ meter (HACH E C20), reflux apparatus, and pH indicator. AAS (Perkin Elmer Analyst 400), SEMEDX (Phenom Pro X Desktop with EDX), and FTIR (Shimadzu Prestige 21) were used to analyze the PEATM ionic imprinted membrane.

\section{Procedure}

\section{PEATM synthesis}

PEATM was synthesized from polyeugenoxy acetic acid (POA) with 2-thiophenemethanol through an esterification reaction. A total of $3 \mathrm{~g}$ POA was refluxed 
with $3 \mathrm{~mL}$ of thionyl chloride for $240 \mathrm{~min}$ at a temperature of $40^{\circ} \mathrm{C} .2 \mathrm{~mL}$ of 2-thiophenemethanol was then added to the mixture and reflux was continued at $40{ }^{\circ} \mathrm{C}$ for $6 \mathrm{~h}$. After chilled, washing was done with chloroform and double-distilled water. The synthesized product was dried at room temperature.

\section{Synthesis of PEATM-Au}

PEATM-Au was synthesized by contacting $1 \mathrm{~g}$ of PEATM with $20 \mathrm{~mL}$ of $1000 \mathrm{ppm} \mathrm{HAuCl}_{4}$. The contacting procedure was done by mixing the mixture for $24 \mathrm{~h}$. Afterward, filtering was performed, and it was then analyzed with AAS. The sediment (PEATM-Au) was later dried and then analyzed using FTIR.

\section{Synthesis of IIM and NIM}

IIM and NIM were synthesized by in-situ method, by mixing $0.25 \mathrm{~g}$ PEATM-Au (for IIM synthesis) and 0.25 g PEATM (for NIM synthesis), $0.5 \mathrm{~g}$ PVA, $0.25 \mathrm{~mL}$ $\mathrm{NaOH}$ 0, $1 \mathrm{M}, 0.3 \mathrm{~mL}$ PEGDE, and $2.5 \mathrm{~mL}$ NMP. The mixture was refluxed for $30 \mathrm{~min}$ at $90-110{ }^{\circ} \mathrm{C}$ until a hydrogel was formed. Once cooled, the gel was weighed and taken $3 \mathrm{~g}$, mixed with $3 \mathrm{~mL}$ of NMP, then was refluxed for $30 \mathrm{~min}$ at a temperature of $110-130^{\circ} \mathrm{C}$. After it was homogeneous, the mixture was then poured into a mold and then heated at $80^{\circ} \mathrm{C}$ until dry in the furnace. $2 \mathrm{M} \mathrm{KCl}$ was poured into the membrane mold until it was submerged and then allowed to stand for 15 min until the membrane could be removed from the mold. The membrane was washed using distilled water to remove excess $\mathrm{KCl}$ and was dried at room temperature afterward.

\section{PEATM characterization}

Synthesized PEATM-Au was characterized by FTIR to identify the functional group and using AAS to detect the remaining levels of $\mathrm{Au}^{3+}$ in the filtrate (after contacting).

Characterization of PEATM. The synthesized PEATM was FTIR to identify the functional group characterized by and molecular weight $(\mathrm{Mv})$ measurement was done using the viscometry method.

Characterization of PEATM-Au. Synthesized PEATM$\mathrm{Au}$ was characterized by an FTIR spectrophotometer to identify the functional group and using AAS to detect the remaining levels of $\mathrm{Au}^{3+}$ in the filtrate (after contacting).

\section{Feed phase $\mathrm{pH}$ optimization}

To determine the optimum $\mathrm{pH}$ of the feed phase, the transport was carried with variations of $\mathrm{pH}$

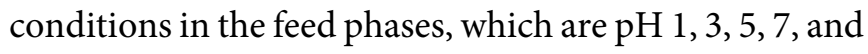
9. Transport was carried out for 24 h. $0.8 \mathrm{M}$ thiourea was used as the transport receiving phase. The feed phase and the receiving phase after the transport were analyzed using AAS to determine the levels of $\mathrm{Au}^{3+}$ metals.

\section{Transport time optimization}

To determine the optimum time of the feed phase, the transport was carried out with variations in transport time of $0,4,8,12,16,20,24$, and $48 \mathrm{~h}$. Transport is carried out at the optimum $\mathrm{pH}$ that has been obtained. $0.8 \mathrm{M}$ thiourea was used as the transport receiving phase. The feed phase and the receiving phase after transport were analyzed using AAS to determine the levels of $\mathrm{Au}^{3+}$ metals.

\section{Selectivity test}

Membrane selectivity (IIM and NIM) was tested through a binary metal ion transport $(\mathrm{Au} / \mathrm{Fe}, \mathrm{Au} / \mathrm{Cd}$, and $\mathrm{Au} / \mathrm{Pb}$ ). Transport is carried out at optimum time and $\mathrm{pH}$ conditions. $0.8 \mathrm{M}$ Thiourea was used as the transport receiving phase. The feed phase and the receiving phase after transport were analyzed using AAS to determine the levels of $\mathrm{Au}^{3+}$ metals to prove the membrane selectivity.

\section{- RESULTS AND DISCUSSION}

The synthesized IIM and NIM have a physical shape of a round flat sheet with a diameter of $\pm 4.5 \mathrm{~cm}$, brownish-yellow color, an average thickness of $0.037 \mathrm{~mm}$, not easily torn, and in a dry state are rigid. IIM is synthesized by an in-situ method. In-situ is a membrane synthesis method that begins with the manufacture of hydrogel polymers from a functional polymer mixture that has a metal ion template as a membrane base with cross-linker agents and solvents refluxed together until it thickens (formed sol), followed by cooling at room temperature until it forms gel solids [13].

In this study, PEATM-Au is used as a functional polymer of the $\mathrm{Au}^{3+}$ ion template. PVA was chosen as a polymer base membrane support and as a plasticizer because PVA is a polymer that is chemically stable, 
hydrophilic, elastic, non-toxic, biodegradable, and not carcinogenic [14]. PEGDE is applied as a crosslinking agent as well as a plasticizer, which will increase the mechanical strength of the membrane. Based on previous studies, PEGDE crosslinked PVA based membranes have been shown to have good mechanical strength as indicated by the results of tensile strength tests [15-16].

\section{Characterization of IIM FTIR}

The success of the IIM synthesis was analyzed from the FTIR spectra in Fig. 1. The IIR FTIR spectra showed that the absorption area of the - $\mathrm{OH}$ group was widening; this indicates the increasing number of hydrogen interactions that made the vibration of the $-\mathrm{OH}$ group weaker [17]. In the IIM the CS group wave number $\left(702.9 \mathrm{~cm}^{-1}\right)$ also shifted to a larger wavenumber $\left(848.68 \mathrm{~cm}^{-1}\right)$, this is likely due to the presence of PEGDE as a crosslinker agent and PVA as a plasticizer on the membrane that experience interaction with PEATM-Au which influences the shift of vibrational wavenumber of CS bonds [17-18]. Based on the plank equation theory, which is the basis in the FTIR analysis, explains that energy is directly proportional to the wavenumber $(\mathrm{E}=$ $h \mathrm{v}$ ), the greater the vibrational energy, the greater the peak of the wavenumber [19].

From the FTIR analysis data, the approximate chemical reactions that occur in IIM synthesis can be described, as shown in Fig. 2. To reassure whether the PEATM has been formed or not, ${ }^{1} \mathrm{H}-\mathrm{NMR}$ spectroscopy could be done and is determined by the appearance of a new peak at $\delta 6.83-7.40 \mathrm{ppm}$ (A) which indicates the presence of thiophene compounds and also at peak

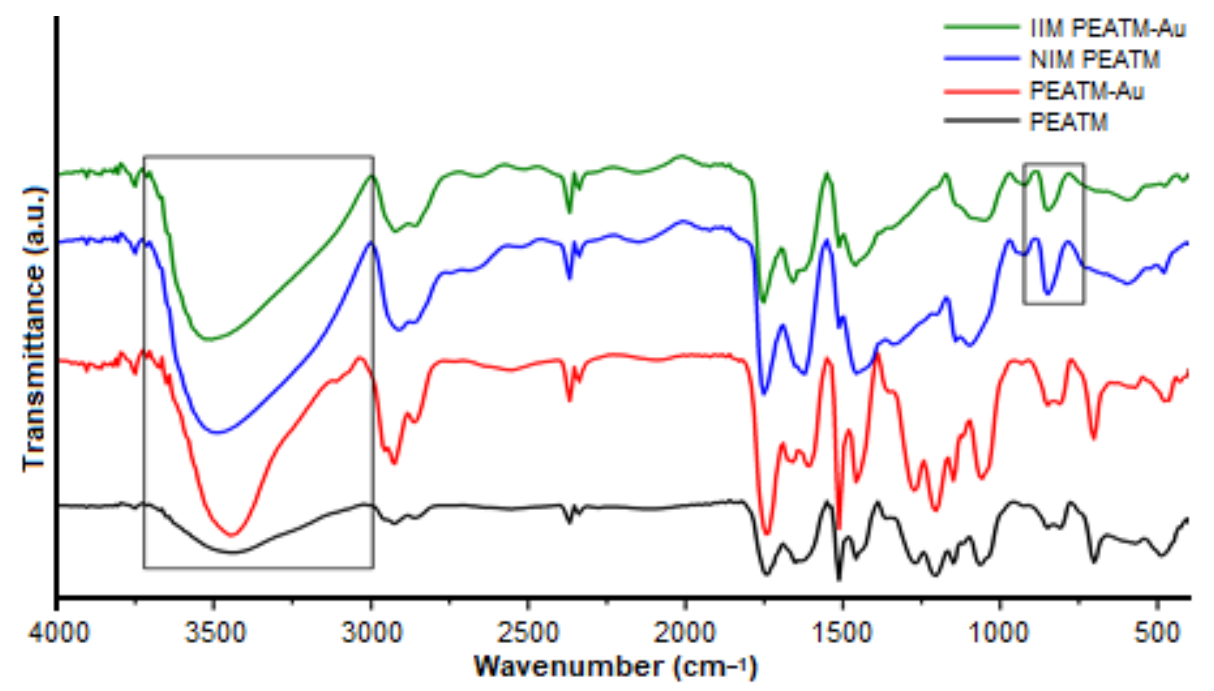

Fig 1. Comparison of IIM, NIM, PEATM-Au, and PEATM FTIR spectra
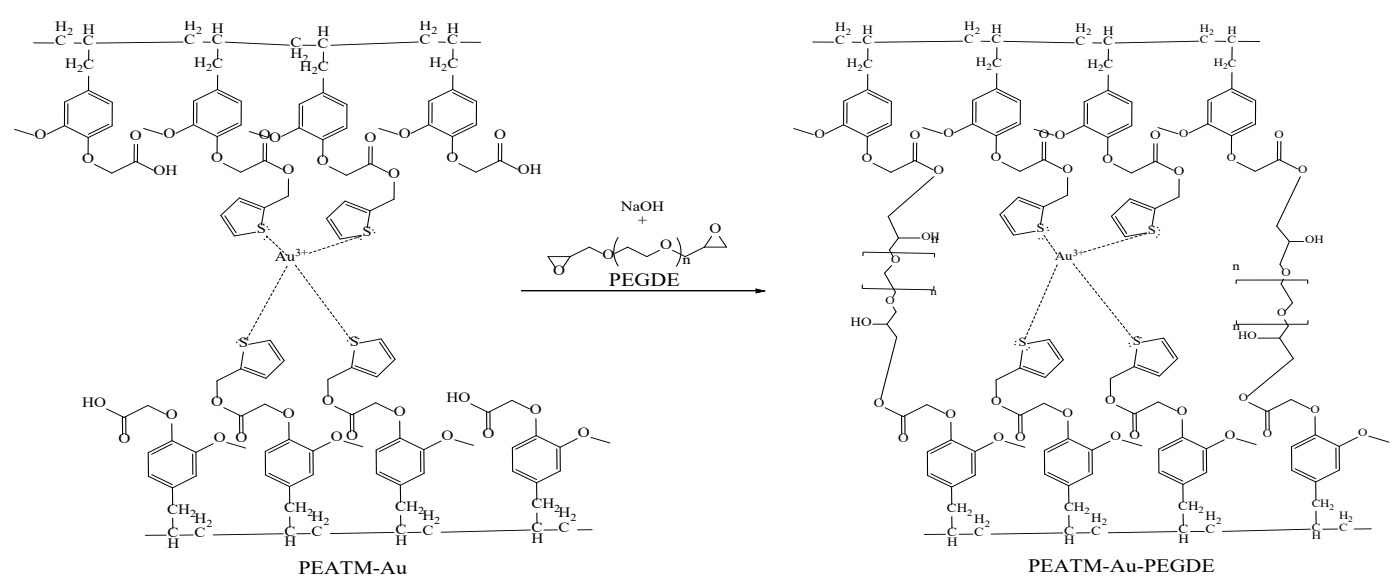

Fig 2. The estimated reaction of IIM synthesis 
$\delta 4.46 \mathrm{ppm}(\mathrm{D})$ and $\delta 4.89 \mathrm{ppm}$, which indicates the presence of a methylene (-CH2-) group [12]. PEATM molecular weight determination was also performed, and the results showed that PEATM synthesized has a molecular weight of $7333,791 \mathrm{~g} / \mathrm{mol}$ with a polymerization degree of 23.

The crosslink reaction in the IIM manufacturing process here, in addition to adding polymer chains and increasing the mechanical strength of the membrane, also plays a role in locking the $\mathrm{Au}^{3+}$ metal ion template on the PEATM polymer, so that an appropriate imprint will be formed [16].

\section{Analysis of SEM-EDX IIM and NIM}

SEM-EDX results in Fig. 3 shows the porous membrane morphology, with an average NIM pore size of $1.80 \mu \mathrm{m}$ and IIM of $1.29 \mu \mathrm{m}$. The pore size at IIM is more uniform and smaller, and this is presumably due to the influence of the printed Au metal ions on the membrane. In the state of the hydrated $\mathrm{Au}^{3+}$ ion species has a radius of $275 \mathrm{~nm}$ [20]. The presence of these Au metal ion molds is expected to increase the membrane affinity for $\mathrm{Au}^{3+}$ ions.

The EDX result for NIM and IIM before and after Au release could be seen in Table 1. From the EDX results obtained, the composition of elements in the membrane and its mass percent. Based on these results, since the $\mathrm{Au}$ on IIM before the release is $75.45 \%$ and after the release is $67.75 \%$, it proves that the gold content $(\mathrm{Au})$ on the membrane is reduced by $7.7 \%$ after removing the template.

\section{Feed pH Optimation}

The feed phase $\mathrm{pH}$ optimization can be determined from the transport percentage curve, as seen in Fig. 4.

The graph shows the optimum $\mathrm{pH}$ of transport with both IIM and NIM is $\mathrm{pH}$ 3. Optimization of this $\mathrm{pH}$ in terms of the feed phase. At $\mathrm{pH} 3$, the remaining percent concentration of metal ions in the feed phase is the least when compared to $\mathrm{pH} 1,5,7$, and 9 . This proves that at $\mathrm{pH} 3$, more $\mathrm{Au}^{3+}$ metal ions are being transported. When viewed from the receiving phase, the greater the $\mathrm{pH}$, the ability to transport $\mathrm{Au}^{3+}$ metal ions will decrease. In a previous study, it was explained that transport to the membrane could occur if the phenolic component is in a dissociated state (the feed phase) and as a phenolate ion (the receiving phase). The acidity conditions in the feed phase affect the phenol transport process. The same thing happens with $\mathrm{Au}^{3+}$ ion transport. In the feed phase,

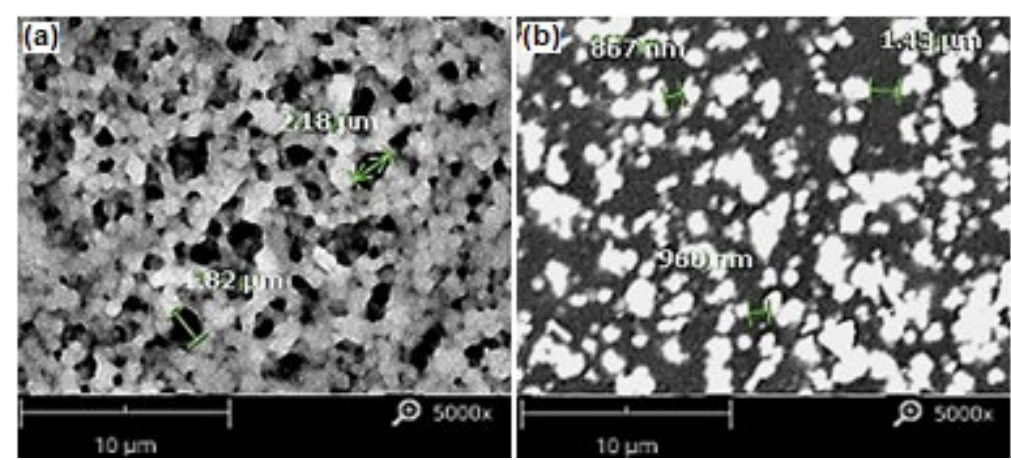

Fig 3. SEM morphology and pore size: (a) NIM, (b) IIM

Table 1. EDX results of NIM, IIM before Au release, and IIM after Au release

\begin{tabular}{cccc}
\hline Elements & NIM & IIM before Au release & IIM after Au release \\
\hline $\mathrm{C}$ & $44.025 \%$ & $16.75 \%$ & $1.74 \%$ \\
$\mathrm{O}$ & $28.875 \%$ & $2.275 \%$ & $2.725 \%$ \\
$\mathrm{~N}$ & $24.47 \%$ & $2.6 \%$ & $6.9125 \%$ \\
$\mathrm{~S}$ & $2.3 \%$ & $1.575 \%$ & $17.5125 \%$ \\
$\mathrm{Au}$ & - & $75.45 \%$ & $67.75 \%$ \\
$\mathrm{~K}$ & $<1 \%$ & $<1 \%$ & - \\
$\mathrm{Cl}$ & $<1 \%$ & $<1 \%$ & - \\
\hline
\end{tabular}


the $\mathrm{Au}^{3+}$ ion species that will be transported to the receiving phase, in the receiving phase in the form of a thiourea solution in acidic $\mathrm{pH}$ of the $\mathrm{Au}^{3+}$ ion species are unstable but will be reduced by becoming $\mathrm{Au}^{1+}$ ions. Thiourea solution under acidic $\mathrm{pH}$ conditions was chosen as the catching phase because based on previous research showed that thiourea in acidic $\mathrm{pH}$ is effective for gold extraction and has several advantages, such as low environmental impact, easier reagent treatment, greater selectivity to gold and faster gold dissolution kinetics [21]. The thiourea solution will then react with $\mathrm{Au}^{1+}$ to produce cationic complexes or aurous ions.

$\mathrm{Au}^{+}+\mathrm{SC}\left(\mathrm{NH}_{2}\right)_{2} \rightarrow \mathrm{Au}\left[\mathrm{SC}\left(\mathrm{NH}_{2}\right)_{2}\right]^{2+}$

The reduction reaction of $\mathrm{Au}^{3+}$ ions to $\mathrm{Au}^{+}$in the receiving phase (thiourea) occurs because the $\mathrm{Au}^{+}$ complex with thiourea is more stable. The stability of the $\mathrm{Au}\left[\mathrm{SC}\left(\mathrm{NH}_{2}\right)_{2}\right]^{2+}$ complex decreases as the $\mathrm{pH}$ of the solution increased, so that the $\mathrm{pH}$ conditions of the feed phases 1 and 3 will make the driving force of the transport of $\mathrm{Au}^{3+}$ metal ions become greater and will decrease with increasing $\mathrm{pH}(\mathrm{pH}=5,7$, and 9). Complex species changes if the $\mathrm{pH}$ of the solution is more than 3 also affects the transport of $\mathrm{Au}^{3+}$ metal ions. As described by Paclawski and Fitzner [22] in the distribution of $\mathrm{Au}^{3+}$ species under various $\mathrm{pH}$ conditions, at $\mathrm{pH}$ more than 3 the presence of hydroxyl ligands begins to replace $\mathrm{Cl}$ ligands so that at $\mathrm{pH}$ above 3 species will exist $\left[\mathrm{AuCl}_{3} \mathrm{OH}\right]^{-},\left[\mathrm{AuCl}_{2}(\mathrm{OH})_{2}\right]^{-}$, $\left[\mathrm{AuCl}(\mathrm{OH})_{3}\right]^{-}$, and $\left[\mathrm{Au}(\mathrm{OH})_{4}\right]^{-}$. The difference in $\mathrm{Au}^{3+}$ metal ion species influences the stability of the complex and causes the transport percentage to decrease as the $\mathrm{pH}$ of the feed phase increased.

\section{Transport Time Optimization}

The results of the optimization of transport time can be described from the transport percentage graph in Fig. 5. Based on the graph in Fig. 5, it showed that the longer the transport time, the transported percentage of

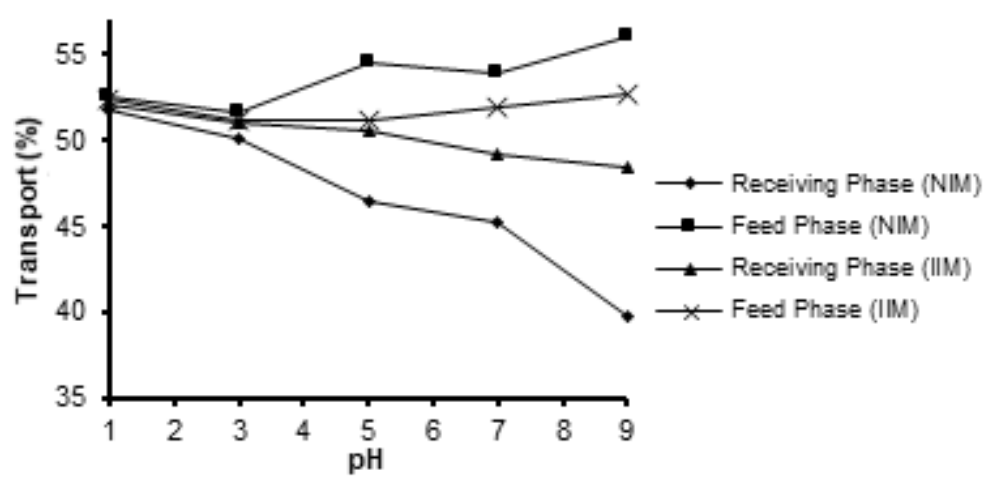

Fig 4. Curve of transport versus $\mathrm{pH}$

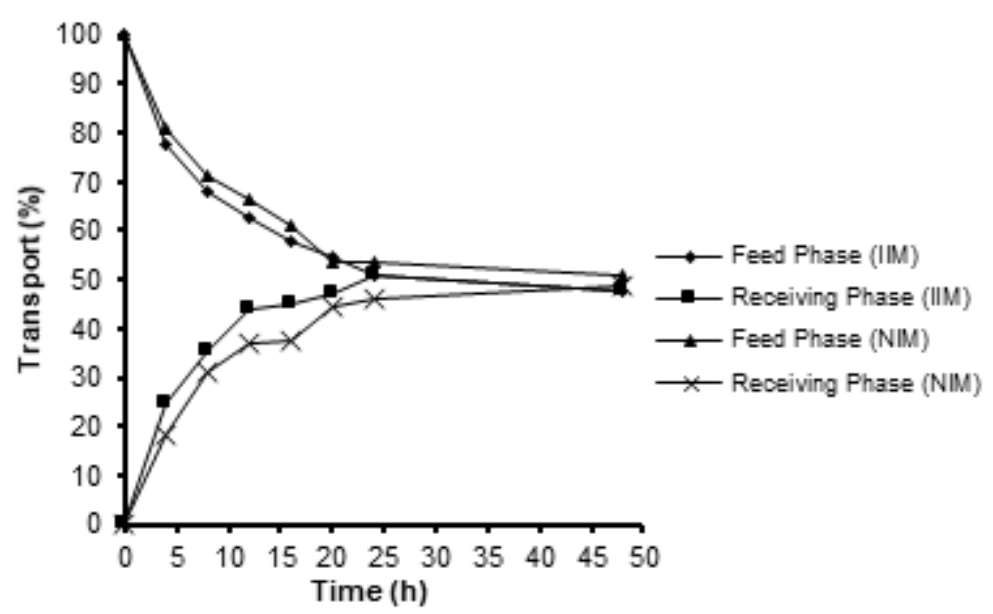

Fig 5. Curve of transport versus time 

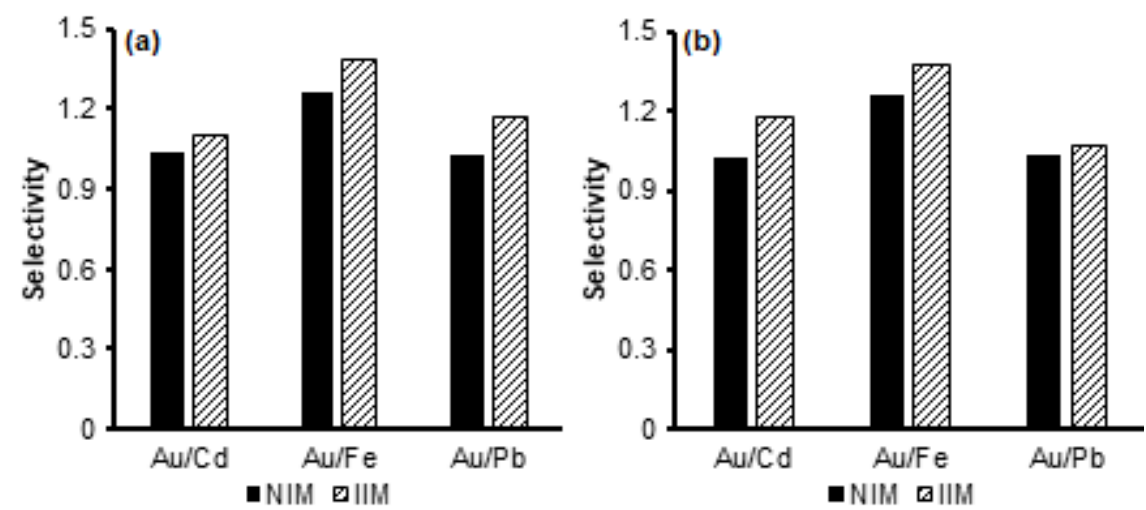

Fig 6. Comparison graph of IIM and NIM selectivity values: (a) Feed phase, (b) Receiving phase

$\mathrm{Au}^{3+}$ metal ions increased when viewed from the receiving phase and decrease when viewed from the feed phase.

This means that the longer the transport time, the greater the concentration of $\mathrm{Au}^{3+}$ metal ions transported. The optimum IIM transport time is achieved at $24 \mathrm{~h}$ and NIM at $48 \mathrm{~h}$, which is indicated by the percent of the transport phase of the receiver, and the remaining percent of the transport phase of the feed is in one point (overlapping). At $24 \mathrm{~h}$, the concentration of Au metal ions in the feed phase is almost the same as the concentration of $\mathrm{Au}$ metal ions in the receiving phase, so there is no driving force due to the effect of different concentrations of the feed phase and the receiving phase. After more than $24 \mathrm{~h}$ to $48 \mathrm{~h}$, there was no change in transport percentages; this indicated that there was no longer a driving force for transport due to differences in the concentration of the feed phase and the receiving phase.

\section{IIM Selectivity to $\mathrm{Au}^{3+}$ Ions}

IIM transport selectivity to $\mathrm{Au}^{3+}$ metal ions is obtained through the transport of binary metal ions. The selectivity value is obtained from the ratio of the transported percentage of the target metal ion to the transported percentage of the competing metal ion. The membrane is said to be more selective about the target metal ion if the percentage of the transport of the target metal ion is greater than that of the competing metal ion, so the membrane selectivity value is more than 1 (selectivity $>1$ ). According to the HSAB theory, $\mathrm{Fe}^{3+}$ is a hard acid, $\mathrm{Pb}^{2+}$ is a borderline while $\mathrm{Cd}^{2+}$ and $\mathrm{Au}^{3+}$ is a soft acid. Since the IIM was made to recognize $\mathrm{Au}^{3+}$ (a soft acid), so the IIM during transport will tend to draw a soft acid rather than those which are not. The results were as expected and can be seen in the graph in Fig. 6 that compares IIM and NIM selectivity values.

The graph in Fig. 6 showed that the selectivity of IIM transport for $\mathrm{Au}^{3+}$ metal ions in all competing metal ion mixture solutions is greater than NIM PEATM. In a solution of a mixture of $\mathrm{Au}^{3+} / \mathrm{Cd}^{2+}$, the selectivity IIM was 1.10, and NIM was 1.03. In a solution of a mixture of $\mathrm{Au}^{3+} / \mathrm{Fe}^{3+}$, the selectivity of IIM was 1.39 , and NIM was 1.26. In a solution of the $\mathrm{Au}^{3+} / \mathrm{Pb}^{2+}$ mixture, the selectivity of IIM was 1.17, and NIM was 1.02. Supported by the selectivity data from the receiver phase in Fig. 6(b), the same thing is also shown. In a solution of a mixture of $\mathrm{Au}^{3+} / \mathrm{Cd}^{2+}$, the selectivity of IIM was 1.18 , and NIM selectivity was 1.02 . In a solution of a mixture of $\mathrm{Au}^{3+} / \mathrm{Fe}^{3+}$, the selectivity of IIM was 1.37 , and NIM was 1.26. In a solution of the $\mathrm{Au}^{3+} / \mathrm{Pb}^{2+}$ mixture, the selectivity of IIM was 1.07, and NIM was 1.03. Previous research on ionic imprinted membrane based on polyeugenol derivates also showed similar results, such as the same optimum $\mathrm{pH}$ condition of 3 and higher adsorption capacity towards $\mathrm{Fe}^{3+}$ when compared to its competitive metal [16]. Through this study, it is proven that IIM is more able to transport Au from its binary mixture selectively.

\section{- CONCLUSION}

This research proves that the presence of $S$ groups in PEATM makes NIM and IIM selective to $\mathrm{Au}^{3+}$ metal ions in accordance with the HSAB theory. The presence of ion templates on the membrane makes IIM have a higher selectivity to $\mathrm{Au}^{3+}$ metal ions compared to NIM. 
The most effective condition for $\mathrm{Au}^{3+}$ metal transport was in $\mathrm{pH} 3$, and the most optimum transport time for IIM is $24 \mathrm{~h}$, while for NIM, it was $48 \mathrm{~h}$. The results showed that IIM has better selectivity towards $\mathrm{Au}^{3+}$ in all mixtures of metal ions compared to NIM. Future studies will probably discuss the membrane applicability for extraction of $\mathrm{Au}^{3+}$ from real wastewater that contains $\mathrm{Au}^{3+}$ and also for the development of gold metal sensing devices.

\section{- REFERENCES}

[1] Ogata, T., and Nakano, Y., 2005, Mechanisms of gold recovery from aqueous solutions using a novel tannin adsorbent gel synthesized from natural condensed tannin, Water Res., 39 (18), 4281-4286.

[2] Lestari, P., 2017, Adsorpsi ion emas menggunakan asam humat tanah gambut di bawah radiasi sinar UV, JST, 6 (1), 168-177.

[3] Torre, M., Bachiller, D., Rendueles, M., Menéndez, C.O., and Díaz, M., 2006, Cyanide recovery from gold extraction process waste effluents by ion exchange I. Equilibrium and kinetics, Solvent Extr. Ion Exch., 24 (1), 99-117.

[4] Rochat, D., Hagelüken, C., Keller, M., and Widmer, R., 2007, Optimal recycling for printed wiring boards (PWBs) in India, R'07 World Congress - Recovery of Materials and Energy for Resource Efficiency, 3-5 September 2007, Davos, Switzerland.

[5] Nghiem, L.D., Mornane, P., Potter, I.D., Perera, J.M., Cattrall, R.W., and Kolev, S.D., 2006, Extraction and transport of metal ions and small organic compounds using polymer inclusion membranes (PIMs), J. Membr. Sci., 281 (1-2), 7-41.

[6] Yoshikawa, M., 2001, Molecularly imprinted polymeric membranes, Bioseparation, 10 (6), 277286.

[7] Vatanpour, V., Madaeni, S.S., Zinadini, S., and Rajabi, H.R., 2011, Development of ion imprinted technique for designing nickel ion selective membrane, J. Membr. Sci., 373 (1-2), 36-42.

[8] Buhani, Narsito, Nuryono, and Kunarti, E.S., 2013, Chemical stability of $\mathrm{Cd}(\mathrm{II})$ and $\mathrm{Cu}(\mathrm{II})$ ionic imprinted amino-silica hybrid materials in solution media, Eksakta, 13 (1-2), 1-10.
[9] Djunaidi, M.C., Khabibi, and Ulumudin, I., 2017, Separation of $\mathrm{Cu}^{+}, \mathrm{Cd}^{2+}$ and $\mathrm{Cr}^{3+}$ in a mixture solution using a novel carrier poly(methyl thiazoleethyl eugenoxy acetate) with BLM (bulk liquid membrane), IOP Conf. Ser.: Mater. Sci. Eng., 172, 012032.

[10] Djunaidi, M.C., Wibawa, P.J., and Murti, R.H., 2018, Synthesis of a carrier compound thiazoethyl methyl eugenoxyacetate from eugenol and its use in the bulk liquid membrane technique, Indones. J. Chem., 18 (1), 121-126.

[11] Qu, R., Sun, C., Wang, M., Ji, C., Xu, Q., Zhang, Y., Wang, C., Chen, H., and Yin, P., 2009, Adsorption of $\mathrm{Au}(\mathrm{III})$ from aqueous solution using cotton fiber/chitosan composite adsorbents, Hydrometallurgy, 100 (1-2), 65-71.

[12] Djunaidi, M.C., Lusiana, R.A., Pardoyo, Widodo, D.S., and Utami, T.W., 2019, Synthesis of polieugenoxy acetyl thiophene methanolate as a new selective carrier, IOP Conf. Ser.: Mater. Sci. Eng., 509, 012068.

[13] Putrie, Z.M., 2013, Sintesis membran hibrida kitosan silika grafting silfonat sebagai proton exchange membran, Master Thesis, Department of Chemical Engineering, Institut Teknologi Sepuluh Nopember, Surabaya, Indonesia.

[14] Bolto, B., Tran, T., Hoang, M., and Xie, Z., 2009, Cross-linked poly(vinyl alcohol) membranes, Prog. Polym. Sci., 34 (9), 969-981.

[15] Merle, G., Hosseiny, S.S., Wessling, M., and Nijmeijer, K., 2012, New cross-linked PVA based polymer electrolyte membranes for alkaline fuel cells, J. Membr. Sci., 409-410, 191-199.

[16] Djunaidi, M.C., Jumina, J., Siswanta, D., and Ulbricht, M., 2015, Synthesis of Fe ionic-imprinted polyeugenol using polyethylene glycol diglycidylether as cross-linking agent for sorption of Fe(III), Indones. J. Chem., 15 (3), 305-314.

[17] González, M.A.G., Edlund, U., Vidaurre, A., and Ribelles, J.L.G., 2017, Synthesis of highly swellable hydrogels of water-soluble carboxymethyl chitosan and poly(ethylene glycol), Polym. Int., 66 (11), 1624-1632. 
[18] Atkins, P.W., and de Paula, J., 2010, Atkins' Physical Chemistry, $9^{\text {th }}$ Ed., Oxford University Press, Oxford, New York.

[19] Marcus, Y., 1991, Thermodynamics of solvation of ions. Part 5.-Gibbs free energy of hydration at 298.15 K, J. Chem. Soc., Faraday Trans., 87 (18), 2995-2999.

[20] Groenewald, T., 1976, The dissolution of gold in acidic solutions of thiourea, Hydrometallurgy, 1 (3), 277-290.
[21] Nicol, M.J., Fleming, C.A., and Paul, R.L., 1992, "The chemistry of the extraction of gold" in The Extractive Metallurgy of Gold, Eds. Stanley, G.G., South African Institute of Mining and Metallurgy, Johannesburg, 831-905.

[22] Pacławski, K., and Fitzner, K., 2004, Kinetics of gold(III) chloride complex reduction using sulfur(IV), Metall. Mater. Trans. B, 35, 1071-1085. 